\title{
Effects of sugammadex on ischemia reperfusion in a rat extremity model
}

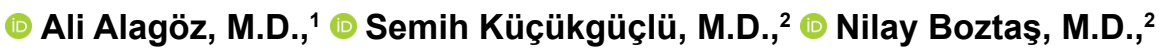

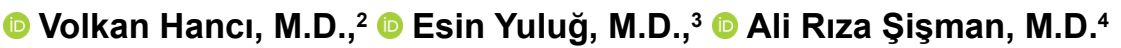

\begin{abstract}
${ }^{1}$ Department of Anesthesiology, Foca State Hospital, İzmir-Turkey
${ }^{2}$ Department of Anesthesiology and Reanimation, Dokuz Eylül University Faculty of Medicine, İzmir-Turkey

${ }^{3}$ Department of Histology and Embryology, Karadeniz Technical University Faculty of Medicine, Trabzon-Turkey

${ }^{4}$ Department of Biochemistry, Dokuz Eylül University Faculty of Medicine, İzmir-Turkey
\end{abstract}

\begin{abstract}
BACKGROUND: The hypothesis of our study is that sugammadex has protective efficacy against ischemia-reperfusion (I/R) injury in rats.

METHODS: Our study included 28 male Wistar Albino rats. The rats were assigned to four groups. The sham group had no procedure other than anesthesia administration. The control group received three hours of ischemia and 24 hours of reperfusion. The $\mathrm{Sgdx} 4$ group received $4 \mathrm{mg} / \mathrm{kg}$, and the Sgdx 16 group received $16 \mathrm{mg} / \mathrm{kg}$ sugammadex intravenously, and then, reperfusion was applied. Histopathological investigation, and serum creatine kinase (CK), lactate dehydrogenase (LDH), and serum and tissue malondialdehyde (MDA) and superoxide dismutase (SOD) analyses were performed.
\end{abstract}

RESULTS: When the sham group and the control group were compared, there were statistically significant differences histopathologically $(p<0.01)$. There was no significant difference between the Sgdx4 group compared with the sham and control groups histopathologically $(p>0.0 I)$. There was a significant difference between the Sgdx I 6 group and the sham group histopathologically $(p<0.01)$. There were significant differences between the sham and control groups concerning CK and LDH levels $(p<0.0 \mathrm{I})$. There was a significant difference in the levels of CK between the control group and Sgdx4 group and in the levels of CK and LDH between the control group and SgdxI6 group $(p<0.01)$.

CONCLUSION: In our study, we examined the histological and biochemical protective effects of $4 \mathrm{mg} / \mathrm{kg}$ sugammadex on unilateral lower extremity I/R injury in rats. The findings suggest that a $4 \mathrm{mg} / \mathrm{kg}$ dose of sugammadex was more effective than a $16 \mathrm{mg} / \mathrm{kg}$ dose.

Keywords: Ischemia; lower extremity; reperfusion; sugammadex.

\section{INTRODUCTION}

Ischemia-reperfusion (I/R) is defined as renewed blood flow to a tissue or organ after a reduction or cessation of blood flow. ${ }^{[1]}$ Reperfusion may cause more injury to tissues compared to the original injury that arises from ischemia, which is called I/R injury. ${ }^{[2]}$ Injury due to I/R is the basis of the physiopathology linked to surgical interventions and thrombolytic treatments like cerebral ischemia, stroke, hemorrhagic shock, aorta/peripheral artery cross-clamping, thromboembolism, myocardial infarction, tourniquet application, and organ transplantation. ${ }^{[3]}$ Skeletal muscle ischemia is generally observed in the lower extremities, together with trauma, hemorrhage, vein blockage, and thromboembolic formations. ${ }^{[4]} \mathrm{I} / \mathrm{R}$ in the lower extremities is a common and clinically important event. In the reperfusion period after extremity ischemia, there is a clear increase in morbidity and mortality as a result of systemic complications. While edema and muscle necrosis may occur locally, problems, such as systemic inflammatory response and multiple organ failure, may be encountered with

Cite this article as: Alagöz A, Küçükgüçlï S, Boztaş N, Hancı V, Yuluğ E, Şişman AR. Effects of sugammadex on ischemia reperfusion in a rat extremity model. Ulus Travma Acil Cerrahi Derg 2020;26:509-516.

Address for correspondence: Nilay Boztaş, M.D.

Dokuz Eylül Üniversitesi Tıp Fakültesi, Anesteziyoloji ve Reanimasyon Anabilim Dalı, İzmir, Turkey

Tel: +90 232 - 41228 $01 \quad$ E-mail: nilayboztas@hotmail.com 
advancing reperfusion. ${ }^{[5]}$ The method used in many operations involving a tourniquet is a model for I/R. The advantages of using a tourniquet include ensuring a bloodless environment and making the operation easier, reducing hemorrhage, limiting transfusion requirements, and surgery duration. ${ }^{[6]}$

Neuroprotective effects of various cyclodextrins have been shown in previous studies. Methyl- $\beta$-cyclodextrin has been found to protect the hippocampal areas from the effects of anoxia. ${ }^{[7]}$ Frank et al. ${ }^{[8]}$ reported that as with other $\beta$-cyclodextrins, methyl- $\beta$-cyclodextrin reduced neuronal excitability in the hippocampal area because methyl- $\beta$-cyclodextrin treatment may separate cholesterol in the postsynaptic area, causing disruption of the NMDA receptor and $\alpha$-amino3-hydroxy-5-methyl-4-isoxazolepropionic acid receptorlinked glutamate transmission.

Many agents have been studied previously to assess their efficacy on I/R. Among these are beta cyclodextrins. Previous studies have shown a variety of beta cyclodextrins to have positive effects on I/R injury. ${ }^{[7,9]}$ Another agent in the cyclodextrin family is the gamma-cyclodextrin of sugammadex, and this compound has begun to be commonly used in anesthesia practice. ${ }^{[10,11]}$ However, in our literature analysis, no study researching the efficacy of sugammadex on muscle I/R injury was found.

Our hypothesis is that Sugammadex has a protective effect on Ischemia Reperfusion injury in the rat extremity model.

This study aims to induce an I/R model by applying a tourniquet to the lower extremity of rats and to assess the effects of intravenous (IV) $4 \mathrm{mg} / \mathrm{kg}$ and $16 \mathrm{mg} / \mathrm{kg}$ doses of sugammadex on skeletal muscle I/R injury.

\section{MATERIALS AND METHODS}

Our study was completed in the Animal Experiments Laboratory after receiving permission from the Animal Experiments Local Ethics Committee (Ethic No: 15/2016. Date 23/03/2016). This study included 28 male Wistar rats weighing from 250-300 g. They were monitored under standard laboratory conditions (12-hour day/night cycle, $20-22^{\circ} \mathrm{C}$, $50 \%-60 \%$ humidity).

Animals were assigned to four groups. Except for the sham group, the three other groups had circumferential pressure applied to the groin of the right hind leg with an elastic bandage ( $1 \mathrm{~cm}$ width, $30 \mathrm{~cm}$ length) to induce lower extremity ischemia.5 Cessation of blood flow to the lower extremity of the animals was assessed using laser Doppler of the femoral artery at the end of the first, second, and third hour.

\section{Experimental Groups}

The sham group ( $n=7)$ : During this study, no other procedure was performed apart from anesthesia administration. No intervention was applied to the right hind leg.

The control group ( $n=7)$ : After anesthesia, a tourniquet was applied to the right hind leg at the hip joint level. Before opening the tourniquet, the rats were given a total volume of I $\mathrm{mL} 0.9 \% \mathrm{NaCl}$ via the tail vein. After three hours of ischemia, 24 hours reperfusion was applied and no treatment was administered.

The Sgdx4 group ( $n=7)$ : After anesthesia, a tourniquet was applied to the right hind leg at the hip joint level. Three hours of ischemia were applied. Immediately before opening the tourniquet, $4 \mathrm{mg} / \mathrm{kg}$ sugammadex (Bridion $200 \mathrm{mg} / 2 \mathrm{~mL}$ vial, Merck Sharp \& Dohme) was administered via the tail vein in a total volume of I $\mathrm{mL}$. Then 24 hours reperfusion was applied.

The Sgdx I 6 group ( $n=7)$ : After anesthesia, a tourniquet was applied to the right hind leg at the hip joint level. Three hours of ischemia were applied. Immediately before opening the tourniquet, $16 \mathrm{mg} / \mathrm{kg}$ sugammadex (Bridion $200 \mathrm{mg} / 2 \mathrm{ml}$ vial, Merck Sharp \& Dohme) was administered via the tail vein for a total volume of $1 \mathrm{~mL}$. Then 24 hours reperfusion was applied.

Doses of sugammadex were determined based on examples of doses used in previous studies with rats and healthy humans. ${ }^{[12,13]}$

The rats were anesthetized with intraperitoneal (ip) $50 \mathrm{mg} / \mathrm{kg}$ ketamine (Ketalar flk., Pfizer Pharma GMBH, Germany) and $10 \mathrm{mg} / \mathrm{kg}$ xylazine hydrochloride (Alfazyne 2\%, Alfasan International, Holland). A tourniquet was applied to the right hind leg to induce ischemia. Ketamine and xylazine doses were repeated every 45 minutes during the ischemia procedure. ${ }^{[5]}$

A venous path was opened in the tail vein, and $5-10 \mathrm{mg} /$ $\mathrm{kg} / \mathrm{h}$ physiological serum was administered to prevent dehydration. Cessation of blood flow was decided based on laser Doppler assessment of the femoral artery and at the end of the first, second, and third hour. After three hours of ischemia, ${ }^{[4,5]}$ immediately before opening the tourniquet, $4 \mathrm{mg} /$ $\mathrm{kg}$ or $16 \mathrm{mg} / \mathrm{kg}$ sugammadex was administered via the tail vein. After administering sugammadex doses intravenously, the catheter was removed.

During the reperfusion period, animals had access to standard rat feed and water until two hours before the surgical procedure. At the end of 24-hour reperfusion, anesthesia was induced in the animals with ip $50 \mathrm{mg} / \mathrm{kg}$ ketamine (Ketalar flk., Pfizer Pharma GMBH, Germany) and 5-10 mg/kg xylazine hydrochloride (Alfazyne 2\%, Alfasan International, Holland).

The right hind leg was dissected, and the gastrocnemius muscle was removed for histopathological investigation. Blood was removed by cardiac puncture for biochemical tests. At 
this time, this study was ended, and the rats were sacrificed by exsanguination.

\section{Biochemical Investigation}

For biochemical investigations, blood samples taken from the heart were assessed for serum CK (creatine kinase) and LDH (lactate dehydrogenase). Malondialdehyde (MDA) from serum and tissue samples and superoxide dismutase (SOD) from serum samples were manually measured using spectrophotometric methods. The serum was placed in biochemical tubes and stored at $-80^{\circ} \mathrm{C}$ until analysis.

Before analysis, muscle tissues were weighed on a sensitive scale and placed in microcentrifuge tubes. During this process, samples were kept on ice and $800 \mathrm{~mL}$ PBS added to them. Tissues were homogenized in microcentrifuge tubes in a tissue lysis device for 180 seconds at $25 / \mathrm{s}$ frequency.

The homogenate was centrifuged at $4^{\circ} \mathrm{C}$ for 15 minutes at $13000 \mathrm{~g}$. After centrifuging, the uppermost supernatant was placed on ice with one portion stored for backup, while another portion was diluted to I:8 with PBS and prepared for MDA analysis.

Tissue and serum MDA levels were measured with a BioVision kit (Cat no: \#K739-100, USA). The method involved forming an MDA-TBA complex between the MDA products in the sample and thiobarbituric acid, which was measured colorimetrically at $532 \mathrm{~nm}$. The serum results were given as micromol/L, with tissue results given as micromol/gram protein and micromol/gram tissue.

Tissue and serum SOD activity was measured using a BioVision kit (Cat no: \#K335, USA). The method is based on the inhibition technique of superoxide anions of SOD in the sample; SOD activity is directly correlated with inhibition rate, and this is measured colorimetrically at $450 \mathrm{~nm}$. Serum results are given as $\mathrm{U} / \mathrm{mL}$, with tissue results given as $U / \mathrm{mg}$ tissue and $\mathrm{U} / \mathrm{mg}$ protein.

\section{Histopathological Methods}

The gastrocnemius muscle tissues from each of the study groups were fixed for 48 hours in a $10 \%$ formaldehyde solu- tion for light microscopy examination, and after fixation, they were washed in flowing water for 24 hours. The samples were passed through a series of increasing degrees of alcohol $(80 \%$, $96 \%, 100 \%$ ) and dehydrated. Transparentized in xylene and was submerged in paraffin blocks. ${ }^{[14]}$ The paraffin blocks were sliced into $5 \mu \mathrm{m}$ sections using a fully automatic microtome (Leica RM 2255, Tokyo, Japan) and placed on light microscope slides. The sections were stained with hematoxylin-eosin $(\mathrm{H}-\mathrm{E})$ to observe and assess general histological structures. ${ }^{[15]}$ They were also stained with Masson's trichrome technique to differentiate better and investigate muscle and connective tissue. ${ }^{[16]}$

The preparations obtained were assessed by an experienced histologist, blind to this study. Assessment of the muscle tissues was performed with an Olympus BX5I (Olympus, Tokyo, Japan) microscope. The findings were photographed at different scales using a camera attachment adapted to the light microscope (Olympus DP7I; Olympus, Tokyo, Japan).

For assessment of lineated muscle tissue, semi-quantitative scoring from 0-3 was assigned for disorganization of muscle fibers, degeneration, inflammatory cell infiltration, vascular congestion, and edema. The scoring for the semiquantitative assessment was $0=$ normal, $\mathrm{I}=$ mild, $2=$ moderate, and 3 $=$ severe. $^{[14]}$

\section{Statistical Analysis}

For statistical analysis, the Statistical Package for the Social Sciences (SPSS) 15.0 program was used. Data with continuous values were shown as mean $\pm S D$. Analysis of data in the groups initially applied the Kolmogorov-Smirnov test and ShapiroWilk test to determine the distribution pattern of data. For data with continuous values, analysis of all groups used the Kruskal-Wallis tests, with the Mann-Whitney $U$ test used for the 2-way analysis of groups. The Bonferroni correction was applied as a post-hoc correction. After the Bonferroni correction, a $\mathrm{p}$-value $<0.0$ I was accepted as statistically significant.

\section{RESULTS}

When the groups were compared concerning histopathological results, there was a significant difference identified between the sham group and the control group for histopathological assessment parameters $(p<0.0 \mathrm{I})$ (Table I). Concerning

Table I. Histological assessment of the groups

\begin{tabular}{lccccc}
\hline Groups & Muscle degeneration & Inflammatory cells & Vascular congestion & Edema & Total score \\
\hline Group Sham & $0.85 \pm 0.37$ & $0.57 \pm 0.53$ & $0.85 \pm 0.37$ & $0.42 \pm 0.53$ & $2.71 \pm 1.11$ \\
Group Control & $2.28 \pm 0.48^{*}$ & $2.42 \pm 0.53^{*}$ & $2.00 \pm 0.8 I^{*}$ & $1.85 \pm 0.37^{*}$ & $8.57 \pm 1.8 I^{*}$ \\
Group Sgdx4 & $1.85 \pm 0.89$ & $2.14 \pm 0.37^{\ddagger}$ & $1.57 \pm 0.53$ & $1.14 \pm 0.69$ & $6.71 \pm 1.97^{\ddagger}$ \\
Group Sgdx16 & $2.57 \pm 0.53^{\dagger}$ & $2.85 \pm 0.37^{\dagger}$ & $2.28 \pm 0.75^{\dagger}$ & $1.57 \pm 0.53^{\dagger}$ & $9.28 \pm 1.79 \dagger$ \\
\hline
\end{tabular}

" $\mathrm{p}<0.01$; Group Sham compared with Group Control; Mann-Whitney U test, Bonferroni correction. ${ }^{\dagger} \mathrm{p}<0.01$; Group Sham compared with Group Sgdx I6 ann-Whitney

$U$ test, Bonferroni correction. ${ }^{\ddagger} \mathrm{p}<0.01$; Group Sham compared with Group Sgdx4; Mann-Whitney U test, Bonferroni correction. 
Table 2. Tissue and serum SOD and MDA values in the groups

\begin{tabular}{lcccccc}
\hline Groups & $\begin{array}{c}\text { SOD } \\
\text { U/mg protein }\end{array}$ & $\begin{array}{c}\text { SOD } \\
\text { Blood }(\mathrm{U} / \mathrm{ml})\end{array}$ & $\begin{array}{c}\text { SOD } \\
\text { U/mg tissue }\end{array}$ & $\begin{array}{c}\text { MDA } \\
\text { Mikromol/gr protein }\end{array}$ & $\begin{array}{c}\text { MDA kan } \\
\text { Mikromol/L }\end{array}$ & $\begin{array}{c}\text { MDA } \\
\text { Mikromol/gr tissue }\end{array}$ \\
\hline Group Sham & $8.23 \pm 1.85$ & $12.05 \pm 0.39$ & $0.74 \pm 0.11$ & $4.24 \pm 1.23$ & $5.98 \pm 2.19$ & $0.38 \pm 0.09$ \\
Group Control & $9.76 \pm 2.48$ & $13.91 \pm 5.10$ & $0.71 \pm 0.19$ & $4.67 \pm 1.12$ & $7.49 \pm 3.51$ & $0.34 \pm 0.08$ \\
Group Sgdx4 & $11.32 \pm 4.07$ & $11.73 \pm 0.41$ & $0.80 \pm 0.25$ & $4.79 \pm 1.55$ & $10.60 \pm 11.89$ & $0.35 \pm 0.13$ \\
Group Sgdx16 & $13.16 \pm 5.50$ & $12.42 \pm 0.42$ & $0.87 \pm 0.37$ & $6.17 \pm 2.59$ & $6.48 \pm 1.60$ & $0.41 \pm 0.16$ \\
\hline
\end{tabular}

SOD: Superoxide dismutase; MDA: Malondialdehyde.

Table 3. CK and LDH values in the groups

\begin{tabular}{lcc}
\hline Groups & CK (IU/L) & LDH (IU/L) \\
\hline Group Sham & $530.7 I \pm I 18.44$ & $746.85 \pm 311.90$ \\
Group Control & $1722.85 \pm 494.94^{*}$ & $1219.00 \pm 416.65^{*}$ \\
Group Sgdx4 & $739.71 \pm 233,70^{\star}$ & $871.28 \pm 319.18$ \\
Group SgdxI6 & $1005.42 \pm 395.74^{\dagger}$ & $653.57 \pm 282.70^{€}$ \\
\hline
\end{tabular}

CK: Creatine kinase; LDH: Lactate dehydrogenase.

* $\mathrm{p}<0.0$ I; Group Sham compared with Group Control; Mann-Whitney U test, Bonferroni correction. ${ }^{\dagger} p<0.01$; Group Sham compared with Group SgdxI6; Mann-Whitney $U$ test, Bonferroni correction. ${ }^{\star} p<0.01$; Group Control compared with Group Sgdx4; Mann-Whitney $U$ test, Bonferroni correction. ${ }^{\epsilon} \mathrm{p}<0.0$ I; Group Control compared with Group SgdxI6; Mann-Whitney U test, Bonferroni correction.

SOD and MDA values obtained from serum and tissue samples, there was no significant difference found between the sham group and the control group $(p>0.01)$ (Table 2$)$. There was a significant difference between the sham and control groups for muscle enzyme levels $(p<0.0 \mathrm{I})$ (Table 3$)$.

When the groups given the study drug were assessed, apart from inflammatory cell inflammation $(p<0.01)$ in the Sgdx4 group, there were no significant differences for other histopathological assessment parameters compared to both the sham and control groups $(p>0.01)$. There was a significant difference identified concerning histopathological assessment parameters between the Sgdxl6 group and the sham group $(p<0.01)$ (Table I).

There were significant differences between the Sgdx4 group and Sgdx 16 group (which had received the study drug), and the control and sham groups concerning muscle enzyme levels $(p<0.01)$ (Table 3$)$. There were no statistically significant differences found for SOD and MDA values obtained from serum and tissue samples for any group $(p>0.01)$ (Table 2$)$.

Evaluation of striated muscle tissue showed normal striated muscle structure in the sham group. Muscle fibers were regularly arranged. The transverse lineations in muscle fibers had normal morphology (Fig. Ia). Assessment of muscle tissue in the control group showed widespread disorganiza- tion and degeneration in addition to normal striated muscle fibers.

There were openings between muscle fibers, widespread inflammatory cell infiltration, and vascular congestion (Fig. Ib). Evaluation of muscle tissue in the Sgdx4 group showed openings between muscle fibers and occasional degeneration of muscle fibers.

We observed vascular congestion between muscle fibers and widespread inflammatory cell infiltration (Fig. Ic).

Muscle tissue evaluation of the Sgdxl6 group found widespread muscle fiber disorganization, degeneration, and openings between muscle fibers. There was vascular congestion between muscle fibers and widespread inflammatory cell infiltration (Fig. Id). Staining with the Masson's trichrome technique allowed clear observations to be made (Fig. 2 a-d).

\section{DISCUSSION}

Using the I/R model induced by applying a tourniquet to the lower extremity of rats, we aimed to assess the histopathological and biochemical effects of $4 \mathrm{mg} / \mathrm{kg}$ and $16 \mathrm{mg} / \mathrm{kg}$ intravenous doses of sugammadex on skeletal muscle I/R injury. We found that I/R injury was prevented in the $4 \mathrm{mg} / \mathrm{kg}$ sugammadex group concerning inflammatory cell formation, $\mathrm{pO}_{2}$, and $\mathrm{pCO}_{2}$; however, the $16 \mathrm{mg} / \mathrm{kg}$ dose was not effective. The injury that arises from $I / R$ and linked to tourniquet use occurs due to functional and metabolic changes in the vascular bed and muscle tissue. There is a correlation between the degree of local and systemic effects occurring after tourniquet use and the inflammation duration. Concerning morphology and histochemistry, the degree of injury varies linked to the duration of tourniquet use. ${ }^{[4]}$ There is a significant link between the ischemic injury and the duration of ischemia. In a lower extremity I/R study, Petrasek et al. ${ }^{[17]}$ identified that by the fourth hour of ischemia, the necrosis rate in muscle tissue was $21 \%$; by the fifth hour, it was $61 \%$, and after the fifth hour, it was $92 \%$.

Blaisdell et al. ${ }^{[4]}$ showed that after three hours of lower extremity ischemia, irreversible histological injury began in muscle tissue and was complete by the sixth hour. 

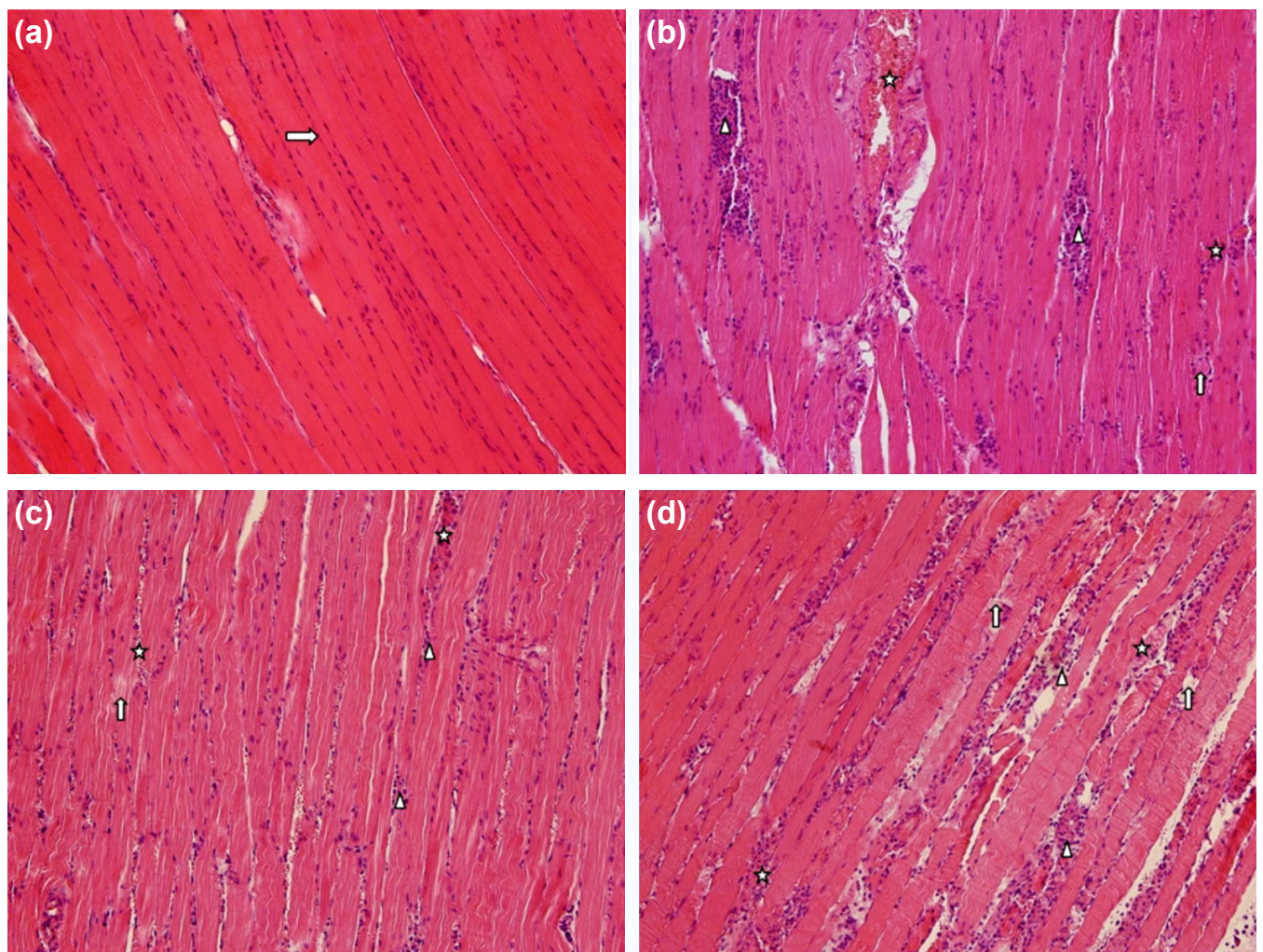

Figure 1. Photomicrograph of lineated muscle tissue (H\&E X 200). (a) Sham Group, (b) Control Group, (c) Sgdx4 Group, (d) Sgdx16 Group. Normal lineated muscle cell $(\rightarrow)$, degenerated lineated muscle cell $(\uparrow)$, inflammatory cell infiltration $(\Delta)$, vascular congestion (star).
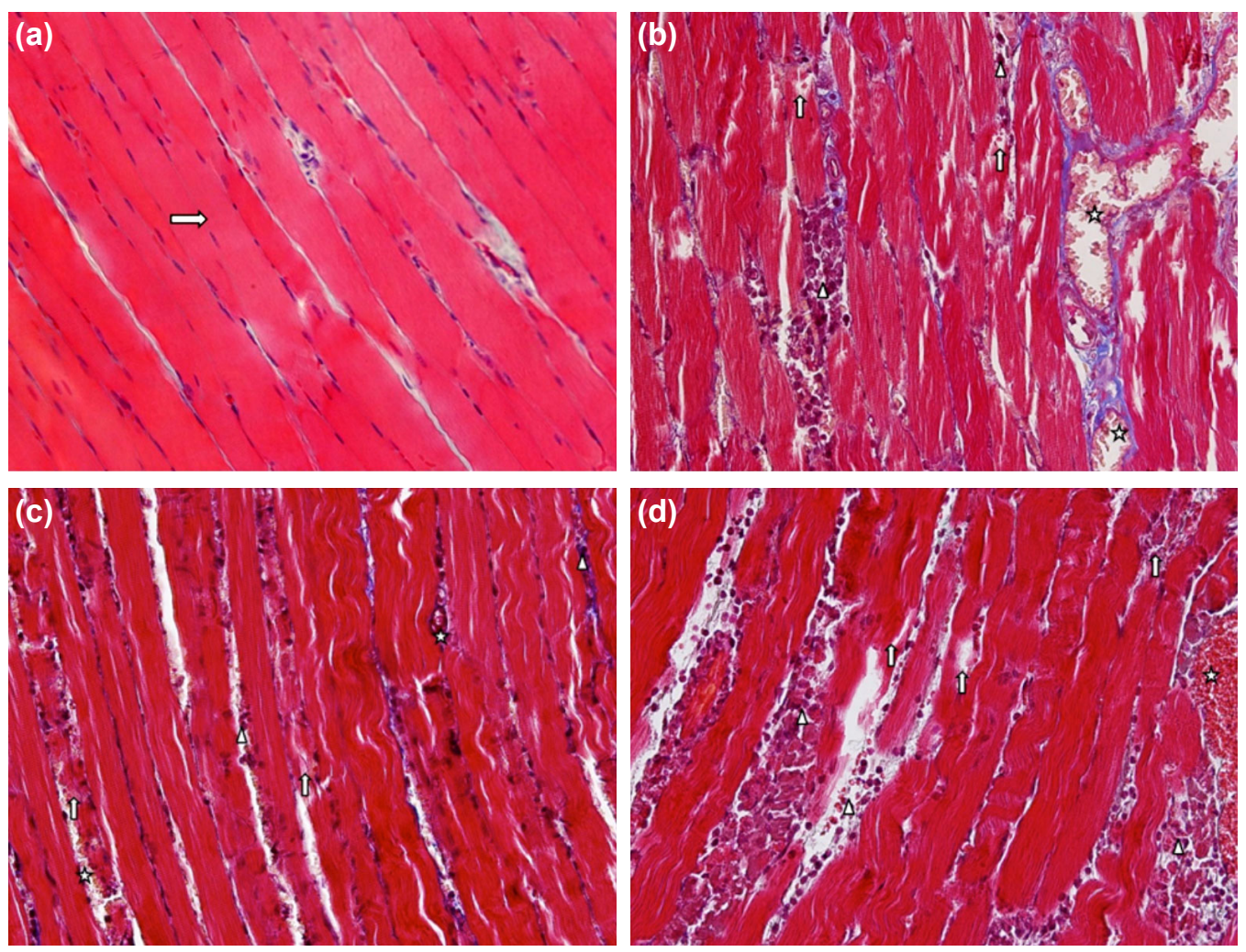

Figure 2. Photomicrograph of lineated muscle cell (Massın trichrome $X$ 200). (a) Sham Group, (b) Control Group, (c) Sgdx4 Group, (d) Sgdx16 Group. Normal lineated muscle cell $(\rightarrow$ ), degenerated lineated muscle cell $(\uparrow)$, inflammatory cell infiltration $(\Delta)$, vascular congestion (star). 
Duru et al. ${ }^{[5]}$ demonstrated widespread neutrophil accumulation in muscle tissue after three hours of ischemia in rats.

In light of these studies, for our experiments, we chose the beginning of irreversible injury (at three hours) for the duration of ischemia. When the sham group and the control group were compared at the end of three hours ischemia, there was a statistically significant difference concerning muscle degeneration, inflammatory cells, vascular congestion, and edema formation.

Carmo-Araújo et al. ${ }^{[18]}$ in a study with four hours ischemia $(I / R)$, four hours ischemia plus one-hour reperfusion (I/R$\mathrm{Ihr}$ ), four hours ischemia plus 24 hours reperfusion (I/R$24 \mathrm{hr}$ ), and four hours ischemia plus 72 hours reperfusion (I/R-72hr) determined that the lesions in muscle samples showed a proportional increase to the reperfusion duration. ${ }^{[18]}$ In our study, we evaluated three hours ischemia, followed by a 24 -hour reperfusion duration.

In previous studies, many agents, such as colchicine, ${ }^{[19]}$ tramadol, ${ }^{[20]}$ silibinin, ${ }^{[21]}$ iloprost, ${ }^{[22]}$ and alpha-tocopherol, ${ }^{[23]}$ have been shown to be beneficial for the amelioration of muscle ischemia-reperfusion injury linked to tourniquet use.

In situations where I/R injury occur, it may be related to a variety of operations and surgeries. In these situations, the efficacy of the anesthetic agents used against I/R injury gains importance.

Agents commonly used in anesthesia practice have been shown to have protective effects against muscle I/R injury, but scientific studies of the new generation of agents are limited, and sugammadex is such an agent. Sugammadex is the first neuromuscular reversal agent with a modified gammacyclodextrin structure to be developed. ${ }^{[24]}$ Sugammadex was designed to reverse the effects of neuromuscular blockers with aminosteroid structure, such as rocuronium and vecuronium, commonly used in general anesthesia. ${ }^{[25]}$

Sugammadex reduces the amounts of rocuronium and vecuronium binding to nicotinic receptors at the neuromuscular junction, and the block occurring at the neuromuscular junction is reversed. ${ }^{[26]}$

The doses of sugammadex used for humans are $2.0 \mathrm{mg} / \mathrm{kg}$, $4.0 \mathrm{mg} / \mathrm{kg}$, and $16 \mathrm{mg} / \mathrm{kg}$. A sugammadex dose of $16 \mathrm{mg} / \mathrm{kg}$ may cause a metallic, bitter taste in the mouth; however, no dose-linked, serious side effects have been encountered. It is recommended that sugammadex not be used for patients with severe renal failure. ${ }^{[27]}$

There has also been a study assessing sugammadex in a global cerebral hypoxia model induced in rats. ${ }^{\left[{ }^{I}\right]}$ This study by $\mathrm{Oz}-$ bilgin et al. ${ }^{[1]}$ involved 10 minutes of global cerebral ischemia in rats followed by 24 -hour reperfusion and used $16 \mathrm{mg} / \mathrm{kg}$ and $100 \mathrm{mg} / \mathrm{kg}$ doses of sugammadex. According to the immunohistochemical assessment of tissue samples from the hippocampus and parietal cortex of the treatment groups, TUNEL results and caspase values were lower than in the cerebral I/R group.

In addition, Ozbilgin et al. ${ }^{\left[{ }^{\prime \prime}\right]}$ showed that a high dose of sugammadex was more neuroprotective and that a high dose of sugammadex had an antioxidant effect. In our study, we used $4 \mathrm{mg} / \mathrm{kg}$ and $16 \mathrm{mg} / \mathrm{kg}$ doses to observe the effects of sugammadex on muscle I/R injury.

Iriz et al. ${ }^{[28]}$ evaluated the antioxidant and cytoprotective effects of iloprost and Vitamin $C$ in a distant organ after abdominal aortic ischemia-reperfusion injury. SOD, MDA and catalase were evaluated in myocardial tissue samples. Oxidative stress markers were significantly lower in iloprost and iloprost + vitamin C groups. Myocardial damage and mitochondrial morphology changes were significantly lower on electron microscopy imaging of myocardial tissue.

Iriz et al. ${ }^{[28]}$ reported that myocardial damage and edema occurred after ischemia-reperfusion of the abdominal aorta and that groups treated with iloprost and iloprost + vitamin C weakened the reperfusion injury of distant organs.

Takhtfooladi et al., ${ }^{[20]}$ in the rat skeletal muscle I/R model with a 2-hour clamp on the femoral artery, followed by reperfusion for 24 hours after the reperfusion of gastrocnemius muscle tissue and blood samples compared to the ischemia group significantly lower values of the group given tramadol, SOD values were found to increase significantly. In another study, Ergün et al. ${ }^{[2]}$ with different doses of cilibiline (50, 100, 200 $\mathrm{mg} / \mathrm{kg}$ ) in the rat skeletal muscle I R model ischemia three hours after two hours reperfusion in all doses of cilibiline tissue MDA values were statistically significant difference compared to the ischemia group. SOD values could not find any difference.

In our study, there was no significant difference between MDA values. The difference in MDA values may be due to differences in ischemia and reperfusion times, or lack of attention to the cold chain during storage or transfer of the MDA kit. Because in our histological evaluation, there was a significant difference in muscle degeneration, vascular congestion, inflammatory cell and edema formation in the control group compared to the sham group. From this point of view, we do not think that there is a tourniquet-induced problem in our rat skeletal muscle I/R model. Concerning SOD values, only $16 \mathrm{mg} / \mathrm{kg}$ and $4 \mathrm{mg} / \mathrm{kg}$ groups were significantly different.

We determined that there was no difference in muscle enzyme levels and histopathological findings between the SGDX4 group and the sham group and that there was a protective effect, but the SGDx 16 group did not have an I/R damaging effect. We determined our doses based on the doses 
used in previous animal experiments and in current clinical administration. As $16 \mathrm{mg} / \mathrm{kg}$ sugammadex is the highest dose for use in anesthesia administration, we chose this dose. ${ }^{[1-13]}$

In a previous study in cerebral ischemia and reperfusion injury, an increased sugammadex dose was found to be related to increasing efficacy. ${ }^{[1]}$

While our study showed a significant difference between the control and sham groups concerning microscopic investigation of skeletal muscle, histopathological scores for skeletal muscle, and skeletal muscle enzyme levels, we did not find any significant difference in tissue and serum MDA and SOD values between any group; this may be due to missing the peak periods concerning MDA and SOD levels.

A limitation of our study is that our study does not include any detailed data related to the mechanism or causes of the difference in response curves. Another limitation of our study is that despite using the ischemia/reperfusion duration used in previous studies, a 24 -hour reperfusion period may have missed the peak period of reperfusion injury.

We hypothesized that, similar to our previous study, ${ }^{\left[{ }^{\prime \prime}\right]}$ the increasing dose would lead to increased efficacy. However, surprisingly, in this study, increased dose did not increase efficacy.

To ensure a better interpretation of these topics following this initial study using sugammadex for I/R injury, we recommend that more in-depth studies should be completed.

Ethics Committee Approval: Approved by the local ethics committee.

Peer-review: Internally peer-reviewed.

Authorship Contributions: Concept: A.A., S.K.; Design: A.A., V.H.; Supervision: A.A., N.B.; Materials: N.B., V.H.; Data: A.A., N.B.; Analysis: V.H., E.Y., A.R.Ş.; Literature search: A.A., N.B.; Writing: A.A., E.Y., A.R.Ş.; Critical revision: A.A., V.H.

Conflict of Interest: None declared.

Financial Disclosure: The authors declared that this study has received no financial support.

\section{REFERENCES}

1. Gute DC, Ishida T, Yarimizu K, Korthuis RJ. Inflammatory responses to ischemia and reperfusion in skeletal muscle. Mol Cell Biochem 1998;179:169-87. [CrossRef]

2. Koksal C, Bozkurt AK, Sirin G, Konukoglu D, Ustundag N. Aprotinin ameliorates ischemia/reperfusion injury in a rat hind limb model. Vascul Pharmacol 2004;41:125-9. [CrossRef]

3. Hobson RW 2nd, Neville R, Watanabe B, Canady J, Wright JG, Belkin $\mathrm{M}$. Role of heparin in reducing skeletal muscle infarction in ischemiareperfusion. Microcirc Endothelium Lymphatics 1989;5:259-76.

4. Blaisdell FW. The pathophysiology of skeletal muscle ischemia and the reperfusion syndrome: a review. Cardiovasc Surg 2002;10:620-30.
5. Duru S, Koca U, Oztekin S, Olguner C, Kar A, Coker C, et al. Antithrombin III pretreatment reduces neutrophil recruitment into the lung and skeletal muscle tissues in the rat model of bilateral lower limb ischemia and reperfusion: a pilot study. Acta Anaesthesiol Scand 2005;49:1142-8.

6. Dammers R, Wehrens XH, oude Egbrink MG, Slaaf DW, Kurvers HA, Ramsay G. Microcirculatory effects of experimental acute limb ischaemia-reperfusion. Br J Surg 2001;88:816-24. [CrossRef]

7. Rivers JR, Maggo SD, Ashton JC. Neuroprotective effect of hydroxypropyl- $\beta$-cyclodextrin in hypoxia-ischemia. Neuroreport 2012;23:1348. [CrossRef]

8. Frank C, Rufini S, Tancredi V, Forcina R, Grossi D, D’Arcangelo G. Cholesterol depletion inhibits synaptic transmission and synaptic plasticity in rat hippocampus. Exp Neurol 2008;212:407-14. [CrossRef]

9. Rufini S, Grossi D, Luly P, Tancredi V, Frank C, D’Arcangelo G. Cholesterol depletion inhibits electrophysiological changes induced by anoxia in CA1 region of rat hippocampal slices. Brain Res 2009;1298:178-85.

10. Palanca JM, Aguirre-Rueda D, Granell MV, Aldasoro M, Garcia A, Iradi A, et al. Sugammadex, a neuromuscular blockade reversal agent, causes neuronal apoptosis in primary cultures. Int J Med Sci 2013;10:1278-85.

11. Ozbilgin S, Yllmaz O, Ergur BU, Hancı V, Ozbal S, Yurtlu S, et al. Effectiveness of sugammadex for cerebral ischemia/reperfusion injury. Kaohsiung J Med Sci 2016;32:292-301. [CrossRef]

12. Hogg RM, Mirakhur RK. Sugammadex: a selective relaxant binding agent for reversal of neuromuscular block. Expert Rev Neurother 2009;9:599-608. [CrossRef]

13. Peeters PA, van den Heuvel MW, van Heumen E, Passier PC, Smeets JM, van Iersel T, et al. Safety, tolerability and pharmacokinetics of sugammadex using single high doses (up to $96 \mathrm{mg} / \mathrm{kg}$ ) in healthy adult subjects: a randomized, double-blind, crossover, placebo-controlled, single-centre study. Clin Drug Investig 2010;30:867-74. [CrossRef]

14. Erkanli K, Kayalar N, Erkanli G, Ercan F, Sener G, Kirali K. Melatonin protects against ischemia/reperfusion injury in skeletal muscle. J Pineal Res 2005;39:238-42. [CrossRef]

15. Stevens A, Wilson I. The haematoxylin and eosin. In: Bancroft JD, Stevens A, editors. Theory and Practice of Histological Techniques. 4th edition: Churchill Livingstone;1996.p.99.

16. Bradbury P, Rae K. Connective tissues and stains. In: Bancroft J, D.Stevens A, editors. Theory and Practice of Histological Techniques. 4th edition. Churchill Livingstone; 1996.p.125-9.

17. Petrasek PF, Homer-Vanniasinkam S, Walker PM. Determinants of ischemic injury to skeletal muscle. J Vasc Surg 1994;19:623-31. [CrossRef]

18. Carmo-Araújo EM, Dal-Pai-Silva M, Dal-Pai V, Cecchini R, Anjos Ferreira AL. Ischaemia and reperfusion effects on skeletal muscle tissue: morphological and histochemical studies. Int J Exp Pathol 2007;88:14754. [CrossRef]

19. Wang L, Shan Y, Chen L, Lin B, Xiong X, Lin L, et al. Colchicine protects rat skeletal muscle from ischemia/reperfusion injury by suppressing oxidative stress and inflammation. Iran J Basic Med Sci 2016;19:670-5.

20. Takhtfooladi HA, Takhtfooladi MA, Karimi P, Asl HA, Mobarakeh SZ. Influence of tramadol on ischemia-reperfusion injury of rats' skeletal muscle. Int J Surg 2014;12:963-8. [CrossRef]

21. Ergün $Y$, Üremiş $M, K 1 \ln$ ç M, Alıcı T. Antioxidant effect of Legalon(r) SIL in ischemia-reperfusion injury of rat skeletal muscle. Acta Cir Bras 2016;31:264-70. [CrossRef]

22. Bozkurt AK. Alpha-tocopherol (Vitamin E) and iloprost attenuate reperfusion injury in skeletal muscle ischemia/reperfusion injury. J Cardiovasc Surg (Torino) 2002;43:693-6.

23. Silva MG, Castro AA, Ramos EA, Peixoto E, Miranda F Jr, Pitta Gde B, et al. Histological and biochemical serum effects of alpha-tocopherol on ischemia/reperfusion-related injuries induced in the pelvic limb of rats. Acta Cir Bras 2005;20:375-81. [CrossRef]

24. Bom A, Bradley M, Cameron K, Clark JK, Van Egmond J, Feilden H, et 
al. A novel concept of reversing neuromuscular block: chemical encapsulation of rocuronium bromide by a cyclodextrin-based synthetic host. Angew Chem Int Ed Engl 2002;41:266-70.

25. Stair C, Fernandez-Bustamante A. Sugammadex, the first selective relaxant binding agent for neuromuscular block reversal. Drugs Today (Barc) 2012;48:405-13. [CrossRef]

26. Miller RD. Sugammadex: an opportunity to change the practice of anes- thesiology?. Anesth Analg 2007;104:477-8. [CrossRef]

27. Hogg RM, Mirakhur RK. Sugammadex: a selective relaxant binding agent for reversal of neuromuscular block. Expert Rev Neurother 2009;9:599-608. [CrossRef]

28. Iriz E, Iriz A, Take G, Ozgul H, Oktar L, Demirtas H, et al. Iloprost and vitamin $\mathrm{C}$ attenuates acute myocardial injury induced by suprarenal aortic ischemia-reperfusion in rabbits. Bratisl Lek Listy 2015;116:627-31.

\title{
DENEYSEL ÇALIŞMA - ÖZET
}

\section{Sıçan ekstremite modelinde iskemi reperfüzyon üzerine sugammadeks'in etkisi}

\section{Dr. Ali Alagöz, ${ }^{1}$ Dr. Semih Küçükgüçlü, ${ }^{2}$ Dr. Nilay Boztaş, ${ }^{2}$ Dr. Volkan Hancı, ${ }^{2}$ Dr. Esin Yuluğ, ${ }^{3}$ Dr. Ali Rıza Şişman ${ }^{4}$}

\author{
${ }^{1}$ Foça Devlet Hastanesi, Anesteziyoloji Kliniği, İzmir \\ ${ }^{2}$ Dokuz Eylül Üniversitesi Tıp Fakültesi, Anesteziyoloji ve Reanimasyon Anabilim Dalı, İzmir \\ ${ }^{3}$ Karadeniz Üniversitesi Tıp Fakültesi, Histoloji ve Embriyoloji Anabilim Dalı, Trabzon \\ ${ }^{4}$ Dokuz Eylül Üniversitesi Tıp Fakültesi, Biyokimya Anabilim Dalı, İzmir
}

AMAÇ: Çalışmamızın hipotezi, sugammadeks'in sıçanlarda iskemi reperfüzyon (I/R) hasarına karşı koruyucu etkinliğe sahip olmasıdır.

GEREÇ VE YÖNTEM: Çalışmaya 28 erkek Wistar Albino sıçanı dahil edildi. Sıçanlar dört gruba ayrıldı. Sham grubuna anestezi uygulaması dışında bir girişim uygulanmadı. Kontrol grubuna 3 saat iskemi ve 24 saat reperfüzyon uygulandı. Sgdks 4 grubu ve Sgdks 16 grubu, intravenöz olarak sırasıyla 4 $\mathrm{mg} / \mathrm{kg}$ ve $16 \mathrm{mg} / \mathrm{kg}$ sugammadeks aldı ve ardından reperfüzyon uygulandı. Histopatolojik inceleme ve serum kreatin kinaz (CK), laktat dehidrojenaz (LDH), serum ve doku malondialdehid (MDA) ve süperoksit dismutaz (SOD) analizleri yapıldı.

BULGULAR: Sham grubu ve kontrol grubu karşılaştırıldı̆ıında, histopatolojik olarak istatistiksel olarak anlamlı farklılıklar vardı ( $p<0.01)$. Sgdks4 grubu ile sham ve kontrol grupları arasında histopatolojik olarak anlamlı fark yoktu $(p>0.01)$. Sgdks I 6 grubu ile sham grubu arasında histopatolojik olarak anlamlı bir fark vardı $(p<0.01)$. Sham ve kontrol grupları arasında CK ve LDH düzeyleri açısından anlamlı fark vardı $(p<0.01)$. Kontrol grubu ile Sgdks4 grubu arasında CK düzeyleri arasında ve kontrol grubu ile Sgdks I 6 grubu arasında CK ve LDH düzeylerinde anlamlı bir fark vardı ( $p<0.01)$. TARTIŞMA: Çalışmamızda, sıçanlarda tek taraflı alt ekstremite I/R yaralanması üzerine $4 \mathrm{mg} / \mathrm{kg}$ sugammadeks'in histolojik ve biyokimyasal koruyucu etkileri incelendi. $4 \mathrm{mg} / \mathrm{kg}$ sugammadeks dozunun $16 \mathrm{mg} / \mathrm{kg}$ dozdan daha etkili olduğunu görüldü.

Anahtar sözcükler: Alt ekstremite; iskemi; reperfüzyon; sugammadeks.

Ulus Travma Acil Cerrahi Derg 2020;26(4):509-5I6 doi: 10.14744/tjtes.2019.12524 